\title{
SOME ASPECTS OF THE PROCESS OF VARROA JACOBSONI MITE ENTRANCE INTO HONEY BEE (APIS MELLIFERA) BROOD CELLS
}

\author{
Michael D. IFANTIDIS \\ Aristotle University of Thessaloniki, School of Agriculture, Laboratory of Apiculture and Sericulture \\ 54006 Thessaloniki, Greece
}

\begin{abstract}
SUMMARY
This paper investigates the phenomenon of temporary immobilisation of female Varroa mites at the bottom of the open brood cells of older bee larvae. The precise time of this functional "Varroa-trap " in worker and drone cells is determined for the first time. The duration of its function amounts to 15 and 45 hours before sealing of the worker and drone cells, respectively. As a rule, no mites will be stuck on the larva food if the host has a weight lower than about $100 \mathrm{mg}$ in worker cells and $200 \mathrm{mg}$ in drone cells.
\end{abstract}

Mites are released from the trap within 6 hours after sealing of worker cells and $20 \mathrm{~h}$ of drone cells. Somewhat less than $5 \%$ of the mites that enter and remain in brood cells are not trapped.

The process of Varroa mite entrance into honey bee brood cells is discussed in relation to its significance for the rate of population increase of the mite and the possibility of a biotechnical method to control varroatosis.

\section{INTRODUCTION}

Reproduction and population growth in the Varroa mite is a complex phenomenon that is affected by several factors, such as :

a) The parasite (age, physiological condition, sperm reserve in the spermatheca).

b) The host (bee species or race, ontogenetic stage, age and sort of the parasitized brood, seasonal condition of the bee colony).

c) The possibility that the female adult mite be found in the sealed bee brood.

The purpose of this paper is to study the process of Varroa mite entrance into honey bee cells and specifically, to determine the time at which it starts the invasion. Worker and drone brood cells are examined separately. The potential application of some aspects of the process to varroatosis control are discussed. 


\section{MATERIAL AND METHODS}

Trapping of the mite in the unsealed brood cell

Combs with unsealed worker and drone brood cells were taken from bee colonies of Apis mellifera L. parasitized by the mite Varroa jacobsoni Oud. Larvae were carefully pulled out of their cells with forceps and weighed individually. The body of the larva and its evacuated cell were examined by using a cold light apparatus.

The weight of the host and the number of parasites in their cells were grouped in classes in two ways.

a) The range of weight of the larva was divided into equivalent classes of $50 \mathrm{mg}$ for drone and $25 \mathrm{mg}$ for worker larvae correspondingly. Weights lower than $200 \mathrm{mg}$ for drone and $100 \mathrm{mg}$ for worker formed a single class. The same was done for weights higher than $350 \mathrm{mg}$ for drone and $150 \mathrm{mg}$ for worker brood. The weight of all larvae that were examined (infested or not) was recorded.

b) The number of trapped mites and the weight of larvae from infested cells were recorded. Uninfested larvae were ignored. Thus, the start and the end point of the weight scale was determined by the lightest and heaviest larva. The range of the weight scale was divided into three equivalent classes.

The individual weight of each larva was converted into the corresponding age by using the equation of Thrasyvouloy and Benton (1983).

\section{Release of the trapped mites in sealed cells}

The number of trapped and free mites in the sealed brood cells was recorded at time intervals of 1 , $2,3,4,6$, and 20 hours after sealing of the cell. The time at which the cells have been sealed was determined as previously described (IFANTIDIs, 1983).

\section{Divergence from the trapping process}

The number of trapped and free mites in worker and drone brood cells in which the sealing process had been started, but not yet finished, was recorded.

\section{RESULTS}

Table 1 is comprised of data collected from all examined drone cells infested or not, while Table 2 is based only on infested cells. Both tables correlate the weight or age of larvae to Varroa infestation.

Table 3 includes data only from worker brood cells.

Table 4 compares the invasion of Varroa in worker and drone brood cells in two colonies. Part I includes absolute numbers of examined and infested cells, number of trapped mites and the infestation parameters. In Part II the relative invasion of the mite in each kind of brood cell can be seen.

Table 5 shows the time after the sealing of the cells at which the temporarily immobilized mites are released in the sealed cell.

The percentage of the mites that enter the brood cells without being trapped is indicated in Table 6. 


\section{DISCUSSION}

\section{Trapping of the mite in the unsealed brood cell}

When parasitizing $A$. mellifera, female adults of the Varroa mite are known to become stuck in the food of older larvae (SAdov, 1981; De Jong et al., 1982 ; IFANTIDIs, 1982). This is a situation Varroa may find when it enters an uncapped brood cell. Obviously, the mite enters this provisional immobilisation accidentally and because of this we call this phenomenon "trapping ". The mite is released from this « trap » when the bee larva consumes the rest of its food.

It is presumed that the mite invasion in the brood cell of its host is partly the result of chemical attraction (Tewarson, 1983). According to Johan et al. (1988) the cell type is also an important factor for the preference of the brood by the mite, but the mechanism by which the mite discriminates between different cell types is not yet clear. Other possible factors, contributing to the process by which Varroa leaves adult bees and enters open cells of older larvae include : a) the behavior of the mite to go between cracks and b) the physical conditions prevailing at the bottom of invaded brood cells. The behavior of the mite is reflected by its tendency to enter and stay between the folds of the abdominal segments of adult bees. This is a behavioral trait of the parasite having obviously significant selective advantages for the mite. It enables the parasite to be carried safely on the host out of the bee colony and, hence, increases the possibility for its expansion through swarming, robbing, or drifting. According to Ifantidis (1982), the same behavioral trait gives the parasite the impulse to start its way to the bottom of the cell. Thus, when it moves on the free surface of an old larva (Fig. $1 \mathrm{~A}$ ), it comes in contact with the cell wall (Fig. $1 \mathrm{~B}$ ) where a crack is formed between larva body and cell wall. The mite goes through this crack and is stuck on larval food. On both adult bees and on larvae, the mite faces the surface that permits it to suck hemolymph from the host. That is why the mite is always found with its back stuck on the food at the bottom of the brood cell (Fig. 2).

The physical conditions that characterize the space at the bottom of the cell of an old bee larva constitutes an ideal trap that, nevertheless, functions to promote the reproduction of the parasite. Without the mechanism of the trap, the mite would be mobile and could jump onto nurse bees as they feed the bee larva. This would effectively lower the mites reproductive success, as it could be removed from the brood cell attached to the adult nurse bee. Thus, without the function of this trap, a relatively smaller number of parasites per unit of time would be found in the sealed brood and, consequently, the rate of mite population growth would be slowed. 




FIG. 1. - A) Female adult of the Varroa mite walking on a round larva in a drone cell, at which the sealing process has been started.

B) The margin of any open drone cell wall is partly displaced so that a Varroa mite can be seen going through the crack which is formed between larva body and cell wall.

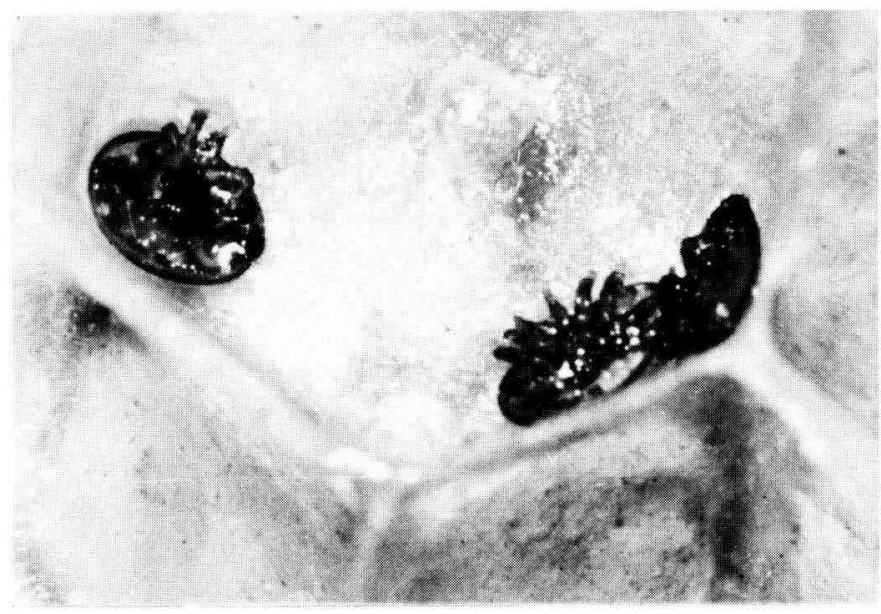

FIG. 2. - Part of an empty open drone brood cell, containing an old larva of the same age as those in Fig. I. Three female Varroa mites can be seen stuck with their back on the larval food at the margin of the cell bottom. 
The number of the immobilized mites at the cell bottom is positively correlated to the duration of the function of the described trap as shown by the data presented in Tables 1,2 and $3(r=0.97,0.90,0.96$ correspondingly). From Tables 1 and 3 it can be seen that no mites are found trapped on the larval food before a certain larval age. In the case of the drone brood this age is about $135 \pm 2 \mathrm{~h}$, while for the worker larvae it is around $105 \mathrm{~h}$ after hatching from the egg. Considering that cell capping occurs 120 hours after hatching of the egg in worker cells and 180 hours in drone cells, it can be estimated that the maximum period of immobilization of adult female mites is $15 \mathrm{~h}$ and $45 \mathrm{~h}$ in the worker and in the drone cells, respectively. This difference must be one of the possible factors resulting in the known « preference " of mites for infesting drone brood compared to worker brood (Sulimanovic et al., 1982).

TABL. 1. - Relation between weight or age of the bee larva and of Varroa infestation in drone brood cells of a honey bee colony.

\begin{tabular}{|c|c|c|c|c|}
\hline \multicolumn{2}{|c|}{ Characteristics of the bee larva } & \multicolumn{2}{|c|}{ Number of cells } & \multirow{2}{*}{$\begin{array}{l}\text { Infestation } \\
\text { rate of cells } \\
(\%)\end{array}$} \\
\hline $\begin{array}{l}\text { Weight } \\
\text { (mg) }\end{array}$ & $\underset{\text { (h) }}{\text { Age }}$ & Examined & Infested & \\
\hline$<200$ & 137 & 37 & 0 & 0.0 \\
\hline 201-250 & $138-149$ & 19 & 1 & 5.2 \\
\hline $251-300$ & $150-161$ & 16 & 2 & 12.5 \\
\hline $301-350$ & $162-172$ & 42 & 14 & 33.3 \\
\hline$>351$ & 173 & 86 & 34 & 39.5 \\
\hline
\end{tabular}

* The age of the bee larva was indirectly determined on the basis of the equation of Thrasyvoulou and BENTON (1982).

TABL. 2. - Relation between weight or age of the bee larva and of Varroa infestation in drone brood cells in two honey bee colonies.

\begin{tabular}{|c|c|c|c|c|}
\hline \multirow{2}{*}{$\begin{array}{l}\text { Code number } \\
\text { of bee colony }\end{array}$} & \multicolumn{2}{|c|}{ Characteristics of the bee larva } & \multirow{2}{*}{$\begin{array}{l}\text { Number of } \\
\text { infested cells }\end{array}$} & \multirow{2}{*}{$\begin{array}{l}\text { Distribution (\%) } \\
\text { of infested cells }\end{array}$} \\
\hline & $\begin{array}{c}\text { Weight } \\
\text { (mg) }\end{array}$ & $\underset{\text { (h) }}{\text { Age * }}$ & & \\
\hline \multirow{3}{*}{1} & $181-247$ & $133-148$ & 6 & 13.96 \\
\hline & 248-314 & $149-164$ & 18 & 41.86 \\
\hline & $314-380$ & $165-180$ & 19 & 44.18 \\
\hline \multicolumn{3}{|l|}{ Total } & 43 & 100.00 \\
\hline \multirow{3}{*}{2} & $201-260$ & $138-151$ & 20 & 16.94 \\
\hline & $261-320$ & $152-165$ & 43 & 36.44 \\
\hline & $321-380$ & $166-180$ & 55 & 46.62 \\
\hline \multicolumn{3}{|l|}{ Total } & 118 & 100.00 \\
\hline
\end{tabular}

* See the comments under Table 1. 
TABL. 3. - Relation between weight or age of the bee larva and of Varroa infestation in worker brood cells in three bee colonies.

\begin{tabular}{c|c|c|c|c}
\hline \hline \multicolumn{2}{c|}{ Characteristics of the bee larva } & \multicolumn{3}{|c}{ Infestation (\%) } \\
\hline \multirow{2}{*}{$\begin{array}{c}\text { Weight } \\
(\mathrm{mg})\end{array}$} & $\begin{array}{c}\text { Age } \\
\text { (h) }\end{array}$ & \multicolumn{3}{|c}{ Code number of colony } \\
\cline { 3 - 5 } & & 3 & 4 & 5 \\
\hline 100 & 105 & 0.0 & 0.0 & 0.0 \\
$101-124$ & $106-113$ & 4.4 & 0.0 & 12.5 \\
$125-149$ & $114-121$ & 8.5 & 19.2 & 19.6 \\
$>150$ & 122 & 23.5 & 26.1 & 25.0 \\
\hline
\end{tabular}

* See the comments under table 1.

Data of Table 4 confirm the higher infestation of drone brood. Infestation levels (percentage of infested cells, cells with more than one mite) are greater in the drone than in the worker cells, independently of the level of colony infestation (colony $\mathrm{n}^{\circ} 6$ was more heavily infested than colony $\mathrm{n}^{\circ} 7$ ).

With this investigation the invasion time of the mite in the brood cell is precisely determined for the first time. The related literature on this point was rather obscure, because not only was the invasion time generalized to be on the last day before cell sealing but no distinction was made between infested drone and worker cells (Sevilia, 1963 ; Chol and Woo, 1973 ; Akratanakul, 1976 ; Grobov, 1977 ; RuttNer and Koeniger, 1979).

TABL. 4. - Comparative data concerning the function of "Varroa-trap " in worker and drone brood cells in A. mellifera $L$. colonies.

\begin{tabular}{|c|c|c|c|c|c|c|c|c|c|c|c|}
\hline \multicolumn{9}{|c|}{ Part I } & \multicolumn{3}{|c|}{ Part II } \\
\hline \multirow{4}{*}{$\begin{array}{l}\text { Code } \\
\text { num- } \\
\text { ber of } \\
\text { colony }\end{array}$} & \multirow{4}{*}{$\begin{array}{l}\text { Kind } \\
\text { of bee } \\
\text { brood } \\
\text { cells }\end{array}$} & \multicolumn{2}{|c|}{ Number of cells } & \multirow{3}{*}{$\begin{array}{l}\text { Num- } \\
\text { ber of } \\
\text { Varroa }\end{array}$} & \multirow{3}{*}{$\begin{array}{c}\text { Cells } \\
\text { with } \\
\text { more } \\
\text { than } \\
\text { one } \\
\text { mite }\end{array}$} & \multicolumn{3}{|c|}{ Infestation parameters } & \multirow{2}{*}{\multicolumn{3}{|c|}{$\begin{array}{l}\text { Relative trapping } \\
\text { effectiveness between } \\
\text { drone and worker cells } \\
\text { concerning the column }\end{array}$}} \\
\hline & & \multirow{2}{*}{$\begin{array}{l}\text { Exa- } \\
\text { mined }\end{array}$} & \multirow{2}{*}{$\begin{array}{c}\text { In- } \\
\text { fested }\end{array}$} & & & \multirow{2}{*}{$\begin{array}{c}\text { Infesta- } \\
\text { tion } \\
\text { rate } \\
(\mathrm{b} / \mathrm{a})\end{array}$} & \multirow{2}{*}{$\begin{array}{l}\% \text { of } \\
\text { cells } \\
\text { with } \\
\text { more } \\
\text { than } \\
\text { one } \\
\text { mite } \\
\text { (d/b) }\end{array}$} & \multirow{2}{*}{$\begin{array}{l}\text { Mites } \\
\text { per } \\
\text { exa- } \\
\text { mined } \\
\text { cell } \\
(\mathrm{c} / \mathrm{a})\end{array}$} & & & \\
\hline & & & & & & & & & (e) & (f) & (g) \\
\hline & & a & b & $\mathrm{c}$ & d & e & f & g & $\mathbf{h}$ & $\mathrm{i}$ & j \\
\hline \multirow{2}{*}{6} & Drone & 79 & 60 & 192 & 41 & 75.9 & 68.3 & 2.43 & \multirow{2}{*}{2.7} & \multirow{2}{*}{4.0} & \multirow{2}{*}{6.9} \\
\hline & Worker & 190 & 53 & 66 & 9 & 27.9 & 17.0 & 0.35 & & & \\
\hline \multirow{2}{*}{7} & Drone & 163 & 52 & 72 & 16 & 31.9 & 30.7 & 0.44 & \multirow{2}{*}{1.9} & \multirow{2}{*}{1.7} & \multirow{2}{*}{2.2} \\
\hline & Worker & 132 & 22 & 26 & 4 & 16.6 & 18.2 & 0.20 & & & \\
\hline
\end{tabular}


Release of the trapped mites in sealed cells

After sealing of the brood cell the mites are progressively released as the larva eats the rest of its food. As can be seen in Table 5, 50\% of the parasites are alrealy free in the worker brood cell one hour after the sealing of the cell. All mites are free from the trap 6 hours after cell sealing. The releasing process of the trapped mites in the drone cells lasts longer, so 20 hours after cell sealing some mites (about $10 \%$ ) can still be found stuck on the larva food.

TABL. 5. - Rhythm with which Varroa mites are set free from their trap in the sealed brood cells of the honey bee.

\begin{tabular}{l|l|c|c|c|c|c}
\hline \multirow{2}{*}{$\begin{array}{c}\text { Kind } \\
\text { of brood }\end{array}$} & $\begin{array}{c}\text { Situation } \\
\text { of mites } \\
\text { in the } \\
\text { sealed cells }\end{array}$ & 1 & 2 & 4 & 6 & 20 \\
\cline { 3 - 7 } & Free & 23 & 19 & 38 & 55 & - \\
\hline \multirow{2}{*}{ Worker } & Trapped & 23 & 3 & 4 & 0 & - \\
\hline$\%$ of free mites & 50.0 & 86.4 & 90.5 & 100 & \\
\hline \multirow{2}{*}{ Drones } & Free & 14 & 9 & - & 13 & 29 \\
\hline
\end{tabular}

Divergence from the trapping process

The data of Table 6 reveal that only a very small percentage of the female adult mites (less than $5 \%$ ) in either kinds of brood cells enters the cells without being trapped in the larval food. In other words, the presence of the mite in the sealed brood cells is mainly due to the existence of the trapping mechanism.

\section{Some further aspects}

The weight of the bee larva must have a direct physical influence on the trapping of the mites. This influence results from the pressure that the body of a growing larva puts on the mite within the sticky food. It is plausible to expect that this pressure increases during the functional period of the Varroa trap, because the body of the larva grows while the cell volume remains 
TABL. 6. - Divergence from the trapping of Varroa mites during the sealing of the brood cells.

\begin{tabular}{|c|c|c|c|c|c|c|c|c|c|}
\hline \multirow{2}{*}{$\begin{array}{c}\text { Kind of } \\
\text { brood cells }\end{array}$} & \multirow{2}{*}{$\begin{array}{l}\text { Situation } \\
\text { of mites }\end{array}$} & \multicolumn{7}{|c|}{ Code number of bee colony } & \multirow{2}{*}{ Total } \\
\hline & & 1 & 2 & 3 & 4 & 5 & 6 & 7 & \\
\hline \multirow{2}{*}{ Worker } & Trapped & 16 & 17 & 42 & 15 & 7 & 9 & 23 & 129 \\
\hline & Free & 0 & 0 & 0 & 1 & 0 & 0 & 2 & 3 \\
\hline \multicolumn{2}{|c|}{$\%$ of free mites } & 0.0 & 0.0 & 0.0 & 6.3 & 0.0 & 0.0 & 8.7 & 2.3 \\
\hline \multirow{2}{*}{ Drone } & Trapped & 23 & 20 & 85 & 19 & 43 & - & - & 190 \\
\hline & Free & 0 & 1 & 0 & 1 & 0 & - & 一 & 2 \\
\hline \multicolumn{2}{|c|}{$\%$ of free mites } & 0.0 & 4.76 & 0.0 & 5.0 & 0.0 & & & 1.0 \\
\hline
\end{tabular}

unchanged. If this is the case, it can be further expected that the functional period of the trap could be shortened by using comb foundations with larger worker cells. Preliminary data obtained by using such foundations (640 cells per $\mathrm{dm}^{2}$ ) indicate that this is possible. We found the weight of bee larvae at which the first mite is trapped was $125 \mathrm{mg}$ in such cells instead of $100 \mathrm{mg}$ as happens in the normal cells (of 840 cells per $\mathrm{dm}^{2}$ ). Further experiments are being made in our Institute to develop a method to control the rate of the population growth of the parasite.

\section{CONCLUSIONS}

Considering the fact the Varroa trap functions three times longer in the drone cell than in the worker cell it can be concluded that this difference constitutes the main reason that drone brood is "preferably " invaded by the parasite compared to worker brood. Without the trapping phenomenon it is likely that a smaller number of female adults of the parasite would be found in the sealed brood and participate in reproduction. If a suitable technique could be developed toward the shortening of the period of function of the Varroa trap, a biotechnical method to control the population increase of the mite could be possible. 


\section{RÉSUMÉ \\ QUELQUES ASPECTS DE LA FAÇON DONT VARROA JACOBSONI PARASITE LES CELLULES DU COUVAIN DE L'ABEILLE (APIS MELLIFICA)}

Ce travail étudie le phénomène d'immobilisation temporaire ( piège ») des varroas femelles au fond des cellules de couvain non operculées des larves d'abeilles âgées.

On a prélevé dans des colonies d'abeilles (Apis mellifica L) parasitées par Varroa jacobsoni Oud. des larves enroulées d'ouvrières et de mâles. On a noté leur poids et leur âge ainsi que le nombre de varroas femelles éventuellement présents, qui étaient collés (" piégés») dans la nourriture larvaire au fond de la cellule examinée (Tabl. 1, 2 et 3) ; les classes de poids ont été déterminées arbitrairement, les classes d'âge calculées selon la méthode de Thrasyvoulou et Benton (1983).

Les premiers varroas piégés ont été trouvés avec les larves d'ouvrières d'au moins $100 \mathrm{mg}$ et avec les larves de mâles de $200 \mathrm{mg}$, ce qui correspond à un âge de 105 et $135 \pm 2 \mathrm{~h}$ respectivement. Il s'ensuit que le "piège à varroas" fonctionne environ $15 \mathrm{~h}$ avec le couvain d'ouvrières et $45 \mathrm{~h}$ avec celui de mâles.

On peut établir d'une façon générale que le nombre de varroas piégés dans les cellules de couvain des deux types augmente constamment depuis le début de fonctionnement du piège jusqu'à l'operculation (Tabl. 1, 2 et 3). La préférence, bien connue dans la littérature, du varroa pour le couvain de mâle a pu là aussi être confirmée (Tabl. 4). Il faut bien sûr considérer - comme montré plus haut - que le piège fonctionne 3 fois plus longtemps avec le couvain de mâle. Les varroas sont libérés au plus tard dans les 6 et $20 \mathrm{~h}$, respectivement, qui suivent l'operculation des cellules d'ouvrières et de mâles, puisque la larve a consommé sa nourriture (Tabl. 5). Seul un petit pourcentage de varroas $(<5 \%)$ n'est pas piégé dans les cellules operculées (Tabl. 6).

Une cause purement physique pourrait être à l'origine du fonctionnement du "piège à varroas ": au fur et à mesure que la larve grossit, celle-ci exerce une pression croissante sur le corps du varroa, qui se déplace vers le fond de la cellule entre la larve et la paroi, puisque la taille de la cellule ne change pas. Il devrait donc être possible, en réduisant cette pression, de raccourcir la phase fonctionnelle du piège et de réduire ainsi le nombre de femelles reproductrices. Les premiers essais pour tester cette hypothèse montrent qu'en augmentant légèrement la taille des cellules $\left(640\right.$ cellules $\left./ \mathrm{dm}^{2}\right)$, les premiers varroas sont trouvés avec des larves d'environ $125 \mathrm{~g}$ (comparaison des données dans le Tabl. 3). Il est donc clair qu'on peut obtenir une réduction de la durée de fonctionnement du piège par un accroissement de la taille des cellules.

\section{ZUSAMMENFASSUNG}

\section{ASPEKTE DES BEFALLS DER BRUTZELLEN DER HONIGBIENE (APIS MELLIFERA) DURCH VARROA JACOBSONI}

In dieser Arbeit wird das Phänomen der zeitweisen Immobilisierung von weiblichen Varroamilben auf dem Boden von offenen Brutzellen mit älteren Bienenlarven untersucht.

Offenliegende Rundmaden in Arbeiterinnen- und Drohnenzellen aus mit Varroa jacobsoni befallenen Völkern von Apis mellifera wurden entnommen. Das Gewicht und das Alter der Bienenlarve sowie die Anzahl der eventuell vorhandenen weiblichen Milben, die am Boden der geprüften Zelle mit dem Rücken festgeklebt waren, wurden registriert (Tab. 1, 2 und 3 ; die Gewichtsklassen in diesen Tabellen wurden willkürlich festgelegt, die Altersklassen nach der Methode von Thrasvvoulou u. Benton [1983] berechnet)

Auf dem Futtersaft festgeklebte Milben findet man frühestens bei Larven von Arbeitsbienen mit mindestens $100 \mathrm{mg}$ oder Drohnenlarven von $200 \mathrm{mg}$., was einem Alter der Larve von 105 bzw. 133-138 h entspricht. Daraus ergibt sich, daß dic "Varroa-Falle» bei Arbciterinnenbrut 15 Stunden bei Drohnenbrut ca. 45 Stunden wirksam ist. 
Allgemein läßt sich feststellen, daß der Befallsgrad bei Brutzellen beider Art vom Anfang der Funktion als Falle bis zur Verdeckelung ständig zunimmt (Tab. 1, 2 und 3).

Die aus der Literatur bekannte Bevorzugung der Drohnenbrut durch die Varroamilbe konnte auch hier bestätigt werden (Tab. 4). Allerdings muß - wie oben gezeigt — dabei berücksichtigt werden, da die Funktion bei Drohnenbrut dreimal länger anhält.

Nach der Verdeckelung der Arbeiterinnen- bzw. Drohnenzellen werden die Milben nach spätestens $6 \mathrm{~h} \mathrm{bzw}$. ca. $20 \mathrm{~h}$ - dadurch, daß die Larve ihr Futter auffrißt - wieder befreit (Tab. 5).

Nur ein kleiner Prozentsatz (weniger als $5 \%$ ) der Milben in den verdeckelten Zelle sind nicht festgeklebt (Tab. 6).

Ein Grund für den Beginn der Wirksamkeit als «Varroa-Falle " könnte auch ein rein physikalischer sein : Der Druck auf den Körper der Milbe während sie zwischen Larve und Zellwand zum Zellboden wandert, erhöht sich mit zunehmendem Larvengewicht, denn die Zellgröße bleibt gleich. Es müßte also möglich sein, durch Verringerung dieses Drucks die funktionale Phase zu verkürzen und damit die Zahl der sich reproduzierenden Weibchen zu verringern. Erste Vorversuche zu dieser Hypothese ergaben, daß bei einer leichten Vergrößerung der Zellen (auf 640 Zellen pro $\mathrm{dm}^{2}$ ) die ersten Milben auftraten, wenn die Larve ca. $125 \mathrm{mg}$ wog (man vergleiche die Daten in Tab. 3). Es ist also offensichtlich, daß durch Vergrößerung der Zellgröße eine Verkürzung der Funktionsperiode erreicht werden kann.

\section{BIBLIOGRAPHY}

Akratanakul P., 1976. - Biology and systematics of bee mites of the family Varroidae (Acari : Mesostigmata) M.S. Thesis, Oregon State University, Corvallis, 64 pp.

CHoI S.Y. and Woo K.S., 1973. - [Studies on the bionomics of the bee mite Varroa jacobsoni Oudemans and its chemical control (I)]. Research reports of the Office of Rural Development, Suwon Korea 15 (Livestock) 35-43. [In Korea : English sumary].

De Jong D., Morse R.A. and Eickwort G.C., 1982. - Mite pests of honey bees. Annu. Rev. Entomol., 27, 229-252.

Grobov O.F., 1977. - Varroasis in bees. In : Varroasis, A Honeybee Disease. Apimondia Publishing House, Bucharest, 46-90.

IFANTIDIS M.D., 1982. - [The ontogenesis of the mite Varroa jacobsoni Oud. unter natural breeding contitions and factors influencing its reproduction and population growth] Dissertation, Aristotle Univ. of Thessaloniki, Greece, 86 p. [in Greek].

- 1983. - Ontogenesis of the mite Varroa jacobsoni in worker and drone brood cells. J. Apic. Res., 22 (3), 200-206.

Johan H., De Ruuter A. and Calis J.N.M., 1988. - Distribution of Varroa jacobsoni Oudemans 1904 female mites in honey bee worker brood cells of normal and manipulated depth. Entomol. Gener (under publication).

Ruttner F. and Koeniger N., 1979. - Experiments to eliminate Varroa mites by biological methods. Apiacta, XIV (4), 159-160 and 163.

SADov A.V., 1981. - [Treatment of bees and viability conditions of Varroa jacobsoni]. Veterinariya (Mosc.), 447-449 [in Russian].

Sevilla V.J., 1963. - Observations on the life history and habits of the three new acarine pests of honey bees in the Philippines. B.Sc. Thesis Coll. Agric. Univ. Philippines, 28 p.

Sulmanovic D., Ruttner F. and Pechracker H., 1982. - [Studies on the biology on reproduction in Varroa jacobsoni]. Honeybee Sci., 3 (3), 109-112 [in Japanese].

Tewarson N.C., 1983. - [Nutrition and reproduction in the ectoparasitic honeybee (Apis sp.) mite Varroa jacobsoni]. Dissertation, Universität Tübingen, 115 p. [in German].

Thrasyvoulou A.T. and Benton A.W., 1983. - Rates of growth of honeybee larvae. J. Apic. Res., 21 (4), 189-192 